Please cite this article as:

Dell'Era C (2010).

Art for Business: Creating Competitive Advantage through Cultural Projects.

Industry and Innovation, Vol. 17, No. 1, Pp. 71-89.

(DOI: 10.1080/13662710903573844) 


\title{
ART FOR BUSINESS: \\ CREATING COMPETITIVE ADVANTAGE THROUGH CULTURAL PROJECTS
}

\author{
Claudio DELL'ERA \\ Department of Management, Economics and Industrial Engineering, \\ Politecnico di Milano - Piazza L. da Vinci, 3220133 Milano Italy \\ claudio.dellera@polimi.it
}

Submission for the Special Issue "Experience the Creativity"

Keywords: art, cultural project, competitive advantage

\begin{abstract}
Today, more than ever, products determine their own market presence through the meanings that they assume and the symbolic value that they exude. For this reason, an increasing number of companies are trying to enrich brands and products with new cultural values and messages. The cultural aspects of products and brands are so relevant that lately several companies and organizations have aimed to link art and business to improve both society and corporate performance. If in the '90s keystone contributions from Pine and Gilmore (1999), Schmitt (1999c), and Schmitt and Simonson (1997) provided interesting and stimulating managerial visions, recent phenomena seem to show the necessity of providing something more than an experience. Gilmore and Pine (2007) describe the concept of authenticity as the new business imperative; Holt (2004) demonstrates the success of some iconic
\end{abstract}


brands with particular cultural connections. Focusing on two Italian companies (Diesel and illycaffè) that do not operate in the cultural industries but can be considered cultural producers, the article analyzes several cultural projects, explaining their potential contribution to the competitive advantage. Collaboration with artists allows these firms to intercept and to interpret emerging cultural phenomena and consequently to anticipate the trends of the future. Cultural projects represent a sort of distributed research project that allows the co-production of future scenarios in collaboration with several categories of actors, such as famous artists, young talents, and consumers. The co-development of cultural projects with external actors allows firms to reinforce connections and build communities of people who share similar visions and values.

\section{INTRODUCTION}

An increasing number of companies are trying to develop brands and products able to capture customers' attention by expressing emotions, messages, and values. What consumers are increasingly seeking in brands and products are new forms of psychological satisfaction that go beyond simple consumption. Today, more than ever, products determine their own market presence not only through their attributes but also through the meanings that they assume, the dialogue that they establish with the user, and also the symbolic value that they exude. Benetton was one of the first companies that attempted to associate products with emerging social movements (Tinic, 1997). In 1989, the company replaced images of models wearing products with a series of symbolic images about social problems such as AIDS, environmental disasters, terrorism, and racism. With its United Colors campaign developed in collaboration with Oliveiro Toscani, Benetton introduced a breakthrough innovation in product advertising; up to that moment, ads had been used to propose goods as solutions to life's problems, but here instead Benetton deleted its products from the advertisements. In this way, the 
company sold a corporation's philosophy. Rather than being a simple series of advertisements, the United Colors campaign became the opportunity to demonstrate that Benetton was a company interested in social issues: "Our strategy of advertising is to 'communicate' to consumers rather than to sell to them. All over the world Benetton stands for multi-culturalism, world peace, racial harmony, a progressive approach toward serious social issues and colorful sportswear" (Benetton Group S.P.A. [Benetton], 1992). The perception of the company changed in a radical way: it went from being a fashion line or, more modestly, a clothing company dedicated to a group of people, to being a company that faces common, daily social problems without targeting specific markets. With this advertising campaign, Benetton shifted from a luxury brand to a mass segment (the most famous and representative product - a simple t-shirt with the writing "UNITED COLORS OF BENETTON" in many possible colors - is inexpensively priced).

In 1985, Absolut asked Andy Warhol what he thought of Absolut Vodka's trademark bottle, and his answer was: "I love the packaging, I love the feeling of it... I want to do something ...". The artist then created his famous work inspired by Absolut Vodka, Absolut Warhol, in this way helping the firm to launch a new expression of Absolut: Absolut Art. This project began in 1985 thanks to this collaboration with Andy Warhol, who, attracted by the design and packaging of the characteristic bottle of Absolut Vodka, decided to paint it in order to develop a new interpretation. In this way, Absolut Warhol was created and with it a new advertising concept, Absolut Art. In fact, the following year Keith Haring created his own painting of the bottle, and from that moment, more than 400 Absolut paintings have come to life thanks to these artists' collaborations (Kenny Scharf, Ed Ruscha, Armand Arman, LeRoy Neiman, Robert Indiana, César, Julia Wachtel, Pierre \& Gilles). To collaborate with Absolut became prestigious, a way to express the artist's own opinion and personality through his or her personal interpretation of the Absolut Vodka bottle. The many years of collaboration with artists and commitment to supporting them have made Absolut an integral part of the art community and not 
just a simple client. Absolut has not exclusively collaborated only with painters but has also worked with other kinds of artists, including sculptors, photographers, architects and designers. This initiative with so many artists (along with still more collaborations with famous fashion designers - Absolute Fashion - and DJs - Absolut DJ) have changed the general perception of the Absolut brand, from merely being a high quality vodka to being a kind of medium. Absolut can now exploit this medium in several ways: for example, it can establish connections between different semantic fields (e.g., art, music, fashion, drink), it can democratize the access to the art and fashion worlds that is commonly allowed only to selected people, and it can interpret emerging cultural phenomena through collaboration with young artists.

"The art world is a great source of inspiration for us; it is also a tool for showing off various interpretations of the dynamic ABSOLUT brand [...]. ABSOLUT has indeed brought culture and art to the masses and in doing so has made more people art savvy than they could probably imagine [...]. Our many years of collaboration and stated desire to respectively support the community of artists who have contributed works have made ABSOLUT a part of that community rather than just a client."

Hervé Landry and Marion Kahan, Curators of Absolut Art

These two brief examples highlight a company's ability to develop brands and products able to express emotions, messages, and values through collaboration with "symbolic creators" such as Oliviero Toscani, a photographer, and Andy Warhol, an artist. According to Darsø (2005, p. 58), "One way to modify business as usual is through the artistic touch, through artful creation. There are many reasons for integrating artistic processes and products within a business, the most common being to increase creativity, improve innovation, foster an acceptance of ambiguity and risk, develop increased 
sensitivity to other individuals and their ideas, and transform culture". Several new organizations have aimed to link arts and business to improve both society and corporate performance. For example, the Arts \& Business group in Britain aspires to be the world's most successful and widespread creative network, aiming to help businesspeople support the arts and to help the arts inspire business people. ${ }^{1}$ Art For Business is a multi-year Italian project dedicated to promoting the value of art to aid creative development in organizations and to encourage the aesthetic sensibility of human resources operating inside them. The aim of Art For Business is to create a wide-ranging discussion on what role antique, modern, and contemporary art can play in a company and its management ${ }^{2}$. The Arts, Aesthetics, Creativity, \& Organization Research Network develops and promotes the field of organizational aesthetics, providing a wide range of forums where researchers interested in connecting art, aesthetics, and creative practice within organizational and work settings can meet, exchange ideas, share resources, and experiment with new methods of thought and practice ${ }^{3}$.

In the following paragraphs, we synthesize the main literature contributions to analyze cultural aspects of brands and products. First, we introduce the concept of symbolic innovation, and then we discuss the topic of cultural branding as a possible next stage of the experience economy.

\section{CULTURAL INDUSTRIES AND SYMBOLIC INNOVATIONS}

Consumers increasingly make brand choices on the basis of the aesthetic and symbolic value of products and services (Bloch et al., 2003; Dumaine, 1991; Schmitt and Simonson, 1997). Postrel (2001 and 2003) underlines the role of the "look and feel" of people, places and things, demonstrating how in many industries a product's aesthetic and symbolic dimensions are increasingly relevant to a

\footnotetext{
${ }^{1}$ www.aandb.org.uk

${ }^{2}$ www.artforbusiness.it

${ }^{3}$ www.aacorn.net
} 
company's success. Hirschman (1982) claims that product innovation may arise from two independent sources: symbolism (intangible attributes) and technology (tangible attributes). Symbolic innovations consist of the assignment of social meaning to a product (or reassignment of new social meaning to an existing product), while technological innovations are those that spring from the addition or alteration of a product's tangible features, which serve to distinguish it from prior models. More specifically, starting from the definition of a symbol as an entity that stands in place of or represents another entity (Smelser, 1973), Hirschman (1982) proposes that an innovation generated primarily through symbolic changes is one that communicates a different social meaning than it previously did. Its physical form can remain predominately unchanged, but the meaning assigned to this form is novel. Stated in cognitive terminology, an object after symbolic innovation possesses different intangible attributes than it did in a previous stage. An intangible attribute is one that is associated with the object by consumers but does not arise from the physical nature of the object itself (Hirschman, 1980). During the 1950s, there was substantial discussion concerning the symbolic aspects of products (Gardner and Levy, 1955; Levy, 1959). As Levy (1959, p. 118) noted, "People buy products not only for what they can do, but also for what they mean." Grubb and Grathwohl (1967, p. 24) deepen this idea, talking about social tools: "A more meaningful way of understanding goods as social tools is to regard them as symbols serving as a means to communicate between the individual and his significant references ... If a symbol is to convey meaning it must be identified by a group with which the individual is associated ... and the symbol must communicate similar meaning to all within the group”. Several studies conducted in fields such as cultural anthropology, cognitive sciences, semiology, sociology of culture, and especially production of culture (Becker, 1974 and 1982, Du Gay, 1997, Peterson and Anand, 2004; Staber, 2008) underline the critical role played by symbolic creators (Hesmondhalgh, 2002) and cultural intermediaries (Hirsch, 1972) in the introduction of symbolic innovations. Cultural production is the process by which cultural products (including goods, artifacts, visual and experiential objects, services, 
and art forms) are created, transformed, and diffused in the constitution of consumer culture (Lash and Urry, 1994). Cultural industries can be defined as those industries concerned with cultural products that have artistic and aesthetic appeal; the process of cultural production is a continuous interplay between cultural producers, cultural intermediaries, and consumers. Aesthetic symbols and meanings emerge through a series of production and consumption processes (McCracken, 1988; Kozinets, 2001, 2002; Aage and Belussi, 2008). Knowledge about the subtle and unexpressed dynamics of cultural models is distributed and tacit; it is not codified in books or in sociological scenarios of the future, as symbolic innovations foresee new meanings able to affect the status quo. Several studies on the production of culture show how innovation in the cultural industries is based on the interaction of several actors, since the knowledge necessary for this innovation is dispersed in the environment (McCracken, 1988; Du Gay, 1997; Kozinets, 2001; Hesmondhalgh, 2002; Solomon, 2003; Peterson and Anand, 2004). Under this model, producers of cultural products represent the first category of cultural actors and include designers, artists, architects, etc.; the second category consists of cultural intermediaries defined as individuals and organizations that manage the communication and distribution of cultural products, and, finally, consumers represent the third category and associate cultural products with meanings and experiences.

\section{FROM EXPERIENTIAL TO CULTURAL BRANDING}

The term "customer experience" has been used in several contexts such as marketing, communication, branding, sponsorship, or shopping mall design. For example, McCann-Erickson World Group, MasterCard, Gillette and the Coca-Cola Company have established separate organizational units dedicated to providing services related to sponsorships and event marketing. From an academic point of view, the concept of "experiential aspects of consumption" appeared at the beginning of the 80s 
when Holbrook and Hirschman (1982), focusing on the symbolic, hedonic, and aesthetic nature of consumption, proposed a general framework to represent typical consumer behaviors. In this paper, they describe the radical changes in the consumption behaviors, from an emphasis on rational choice to the "experiential view" where fantasies, feelings, and fun play a fundamental role. In the following years, some authors began to focus on the exploration of the imaginative, emotional, and evaluative components of the consumption experience. For example, Peterson et al. (1986) is an entire collection of papers dedicated to the role of emotions in the experiential consumption; Havlena and Holbrook (1986) assesses the comparative reliabilities and validities of two competing typologies of emotion as applied to the representation of experiences associated with consumption; in the ' 80 s, only some empirical works examined the relationships between emotional benefits and consumption experience, but Holbrook et al. (1986) can be considered an exception, having studied the levels of the emotional and intangible relative to the rational and tangible benefits provided by 53 categories of products. In 1984, Holbrook et al. (1994) analyzes the entertainment industry, measuring the emotional responses involved when playing a video game. Although some attention was also dedicated to the satisfactions derived from leisure activities (Hawes, 1978; Tinsley and Kass, 1978; Unger and Kernan, 1983), these papers do not clarify the role of emotion in consumption. In the second half of the '80s, many studies on the role of emotions in advertising were developed (Holbrook and O'Shaughnessy, 1984; Gardner, 1985; Batra and Ray, 1986; Mizerski and White, 1986), but they only partially addressed some aspects connected to the customer experience.

In the '90s, customers' needs changed completely: functional features and technological performances, product quality and a positive brand image were considered given; customers desired products, communications and marketing campaigns that stimulated their senses and could be incorporated into their lifestyles (Schmitt, 1999c). For this reason, many scholars in the last 15 years have focused their attention on the fields of experiential marketing and experience economy (Pine and Gilmore, 1998; 
Pine and Gilmore, 1999; Schmitt and Simonson, 1997; Schmitt, 1999a; Schmitt, 1999b; Schmitt, 1999; Addis and Holbrook, 2001; Berthon et al., 2003; Fulberg, 2003; Joy and Sherry, 2003; Arvidsson, 2005). The concept of "experience economy" was proposed by Pine and Gilmore in 1999; in their book The Experience Economy - Work is Theatre \& Every Business a Stage, the authors explore how successful companies, using goods as props and services as the stage, create experiences that engage customers on a personal level. Around the same time, Schmitt published the book Experiential Marketing - How to Get Customers to Sense, Feel, Think, Act and Relate, contrasting traditional marketing with a new approach called "experiential marketing"; here, the author shows how managers can create holistic experiences for their customers through brands that provide sensory, affective, and creative associations as well as through lifestyles marketing and social identity campaigns. Schmitt (1999a) underlines the radical shift of the consumer role from traditional marketing, which conceptualizes consumers as rational decision-makers who care about functional features and benefits, to experiential marketing, which considers consumers to be rational and emotional human beings who are concerned with achieving pleasurable experiences. Schmitt (1999c) also suggests that experiential marketing offers a new approach to branding. If the traditional approach treats a brand as a static identifier through the use of names, logos, and slogans, the experiential approach considers brands to be experience providers; according to this new approach, products, merchandising materials, and design elements in the stores have to appeal to all five senses of the customers and capture their hearts and minds. Companies have to connect the brand to customers' interests and lifestyles.

Some phenomena appear to exemplify the necessity of providing something greater than an experience, or perhaps of enhancing it by adding new content. In their recent book, Gilmore and Pine (2007) describe the concept of authenticity as the new business imperative; especially through the case studies of Disney and Starbucks, they show that today's consumers are looking for authenticity where and when they buy. Holt (2003) mentions icons, suggesting that every society needs myths, simple stories 
that help people deal with tension in their lives. The academic disciplines that study mass culture such as anthropology, sociology, history, mass communications, and film criticism have analyzed why cultural icons take on such deep and pervasive meaning in society, concluding that icons come to represent a particular kind of story and are used by consumers to address identity desires and anxieties. In his book How Brands Become Icons - The Principles of Cultural Branding, Holt presents an entirely different model for brand strategy, unlike the experiential approach, which bases its success on deep interpersonal relationships between company and consumer, the cultural approach highlights the success of some iconic brands with particular connections to culture. Customers value the brand stories of Coke, Budweiser, Nike, and Jack Daniel's for their identity value (Holt, 2004). Many other differences between the experiential approach and the cultural approach exist, but perhaps the most important refers to the customers' role; while in the former, the customers' main objective consists of the interaction with the company, in the latter, customers can personalize the brand's myth in order to fit individual biography. Holt (2002) claims that consumers are looking for brands that allow them to develop and enrich their own identity projects. Brands able to match consumers' imaginations, to inspire, provoke and stimulate their cultural reflections, to help them in the interpretation of the world that surrounds them, will be very successful.

\section{METHODOLOGICAL APPROACH}

The article focuses on two companies (Diesel and illycaffè) that do not operate in the cultural industries but have developed several cultural projects. In this way, we want to highlight possible objectives and potentialities of cultural projects developed by companies that operate in industries such as Food \& Beverage or Clothing. As previously mentioned, the article focuses on two leading Italian companies: Diesel is an innovative international design company, producing a wide-ranging collection of jeans, 
casual clothing, and accessories, while illycaffè produces and sells a unique single blend of premium quality coffee worldwide. Both companies can be interpreted as cultural producers; they consider art and culture as central values of their activities.

"We seek to set a world benchmark for excellence and culture in the coffee business, as an innovative company developing the most desirable products and places of consumption, and as a result, to grow and become the global leader of the premium market segment.",

Each day in the international artistic panorama, new talents looking for a stage on which to express themselves emerge. Diesel strongly believes in young creativity, engaging its international network to discover, support, and give voice to raising stars. Fashion, art, design, music, and new media are the areas of interest where Diesel develops innovative and original projects both on an international and on a local level. illycaffè invests in contemporary art projects that bring together countries and cultures, young and old, small towns with large cities. Coffee has long been linked to creativity, expression and discussion, and illycaffè has always had an unflagging passion for the arts-literature, painting, film, design, and architecture — sponsoring, supporting, or commissioning a large number of creative projects over the years. We use the case study methodology approach, which allows us to develop a holistic and contextualized analysis; this method is properly suited to the exploratory nature of this research, as it allows us to explore this phenomenon in its complexity. Each case study was developed using a brief questionnaire to gather background information about the company as well as two in-depth interviews with the Marketing Director and the Head of Communication, which allowed us to identify specific cultural projects. We then interviewed those responsible for each cultural project. Finally, we retrieved

\footnotetext{
${ }^{4}$ http://www.illy.com/wps/wcm/connect/US/illy/about-illy/mission-vision-and-values/mission-vision-values.
} 
additional data through secondary resources, triangulating all information. In the following paragraphs, we introduce both case studies, describing and classifying the cultural projects that they manage. Then, we discuss the strategic role of the cultural projects. Finally, we discuss the principal managerial implications, underlining limits and possible future researches.

\section{DIESEL, PROVOCATIVE CULTURAL PRODUCER}

Diesel is a leader in pioneering new styles, fabrics, manufacturing methods and quality control to guarantee an outstanding product. The company, founded in 1978 by Renzo Rosso, is present in over 80 countries with over 5,000 points of sale and 280 single-brand stores. Diesel is particularly famous for its provocative image; the founder selects creative and talented people who reject the slavish trendfollowing typical of the fashion industry. The members of the Diesel's design team have to express their own personal tastes, forgetting how style is dictated and the tastes of consumers are forecast by the fashion establishment.

"The Diesel style is my lifestyle. [...] Diesel is not my company, it's my life." Renzo Rosso, President - Diesel

The consolidated turnover of the Diesel Group is almost one billion Euro, $85 \%$ of which is generated outside Italy, and the company's employees number 3,400 worldwide. In the last ten years, Diesel has been involved in different cultural projects $^{6}$ : Diesel-U-Music is an international competition for

\footnotetext{
${ }^{5}$ Citations from http://www.businessweek.com/archives/1996/b3473083.arc.htm and http://www.fashionmission.nl/fashion_label_category_d_diesel-0004770007.dfs.

${ }^{6}$ In the article, we focus on cultural projects that have been developed by Diesel for several years and are now directly managed by the Italian company. For example ITS (International Talent Support) is a competition for fashion students and young designers sponsored by Diesel. The Raindance Film Festival is another cultural project sponsored by Diesel.
} 
underground musicians, while Diesel Wall (Italy) and DNA - Diesel New Art (Scandinavia) are national projects. All projects are organized annually; the following timeline highlights the first year of each initiative (see Figure 1).

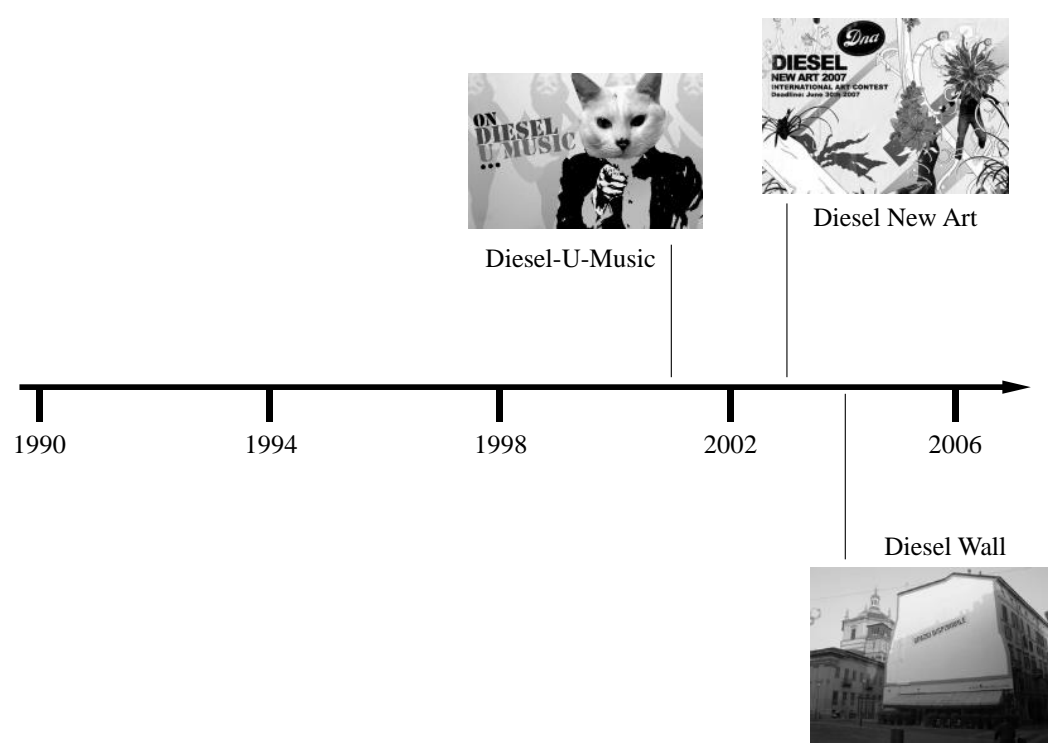

Figure 1: Timeline of cultural projects developed by Diesel

\section{Diesel U-Music (2001-) $)^{7}$}

Diesel-U-Music is an international music competition among artists and unknown bands looking for the occasion to become famous. It has supported the very best of unsigned and unseen underground talents since 2001 and invites "upcoming musicians, DJ's, bands and producers to come out of their bedrooms and garages and express their musical attitudes" ${ }^{\prime 2}$ The initiative is organized in collaboration with independent underground record labels, producers, agencies and reputable magazines; rather than rewarding already rich and famous musicians, the contest aims to provide an alternative stage for new and undiscovered talents.

\footnotetext{
${ }^{7}$ www.diesel-u-music.com

${ }^{8}$ www.diesel-u-music.com
} 
"Diesel offers the possibility to the young artists to emerge. It gives to everybody the opportunity to be known and to put his/her music on internet, without any kind of commercial objective." ${ }^{\prime \prime}$

Miguel Ares, Interactive Marketing Manager - Diesel

Participants can submit demos for one of the following categories: rock, dance, electronic, or urban. These categories were carefully identified at the inception of the competition in order to link the company with social and cultural groups that, on the one hand, can interpret Diesel as a brand able to enrich their identities and, on the other hand, can nurture the values of a company that anticipates upcoming cultural trends and phenomena. Partners of the Diesel-U-Music competition judge the submitted demos to assign prizes such as equipment, management advice, studio time, tour spots, club gigs and performances, studio gear, press coverage and media exposure. The web site www.diesel-umusic.com was developed not only to support the already-established event schedule but also to provide a platform that young and aspiring musicians could use to communicate with each other and stay informed about the latest news and developments in the world of music. In this way, the Italian company has also supported the development of a community that shares cultural values and a cultural identity with the brand.

\section{DNA - Diesel New Art (2003-2007)}

Diesel New Art is an art competition that began in 2003. The first edition was organized in Sweden with the aim of disseminating innovative forms of art, design and music. Since 2004, the competition has expanded to include Denmark and Norway as well. The reward is several cash prizes and the

\footnotetext{
${ }^{9}$ Interview developed by Claudio Dell'Era (February 12 $\left.2^{\text {th }}, 2007\right)$.
} 
chance to exhibit selected works in a touring exhibition that visits Copenhagen, Oslo and Stockholm. DNA promotes several forms of contemporary art; the competition is organized around four different categories: the drawing gallery (gallery dedicated to paintings and drawings), the action gallery (collections of installations, sculptures and forms of conceptual art), the digital gallery (music, film and websites) and the photo gallery (a gallery dedicated to photography). All participants are evaluated by a jury composed of famous artists, collectors, designers, musicians, journalists and administrators of art shows. If Diesel-U-Music is a competition that applies few implicit filters, such as the capability to produce music and an interest in a specific category (rock, dance, electronic or urban), Diesel New Art is a completely open competition both in terms of required capabilities and categories of art.

\section{Diesel Wall (2004-) ${ }^{10}$}

The Diesel Wall project, started in 2004, aims to facilitate people's approach to contemporary art by encouraging a greater number of people to create art in public spaces. Young emergent artists are asked to exhibit their artistic and creative abilities in the heart of the city so as to make an impression on the minds of the people who live there. Initially the project was organized in two cities (Milan, Italy and Berlin, Germany) and aimed to encourage the use of the wall as a versatile space where one might freely exhibit contemporary art. In the following years, the project was expanded to other cities such as Beijing, Toronto, and Barcelona. Located in the lively Ticinese district in Milan, near the historic "Colonne di San Lorenzo", Diesel Wall is a competition that gives talented people the opportunity to realize their artistic visions using one of the most significant public surfaces in the city. The 360 sqmeter wall is a memorial of the history and culture of Milan: damaged during the Second World War, it is now under the protection of a committee that wants to preserve it from demolition in favor of a new building. This cultural project demonstrates an interesting way of approaching city communities. In

\footnotetext{
${ }^{10}$ www.diesel.com/cult/wall/
} 
fact, it identifies urban locations where it is possible to exhibit new forms of visual representation, organizes great events in non-conventional spaces and gives exposure to the new languages of contemporary art. It makes it possible for young emergent artists to value the urban environment, showing new forms of art in a different context than that provided by galleries or museums.

"The purpose is to bring the art to the people." 11

Antonella Viero, Head of Communication - Diesel

\section{ILLYCAFFÈ, AUTHENTIC ITALIAN COFFEE}

Founded in 1933 in Trieste (Italy), illycaffè is one of the most famous coffee manufacturers in the world. Today, Andrea Illy is the CEO of the company, and, as was true for his two predecessors, his principal objective is to improve coffee quality for both the industry and the consumer. During the last five years, the company has expanded its penetration of the global market to include 140 countries and has increased revenues by well over 130 percent. The illycaffè Spa group controls ten companies worldwide, all dedicated to the brand's distribution on international markets. Globally, the group employs more than 700 people. illycaffè has tripled its turnover over the last ten years; in 2007, its turnover was 270 million euros. illy is available in more than 50,000 of the world's finest restaurants, hotels and coffee bars and is sold in over 140 countries on 5 continents.

Since 1992, illycaffè has continuously developed several cultural projects that allow it to connect its brand with the worlds of art, literature and creativity. The first cultural project, started in 1992, was illy Art Collection, which aimed to periodically develop sets of truly special coffee cups interpreted by great contemporary artists: Michelangelo Pistoletto, Marina Abramovic, Sandro Chia, Louise

\footnotetext{
${ }^{11}$ Interview developed by Claudio Dell'Era (January $\left.18^{\text {th }}, 2007\right)$.
} 
Bourgeois Julian Schnabel, Robert Rauschenberg, Jeff Koons, Joseph Kosuth, and James Rosenquist. Legendary filmmakers Federico Fellini and Francis Ford Coppola and musician David Byrne have also been inspired by illycaffè. During the following years, the Italian company introduced a series of cultural projects such as In Principio, illywords, illystories and more recently Galleria illy (see Figure $2)^{12}$.

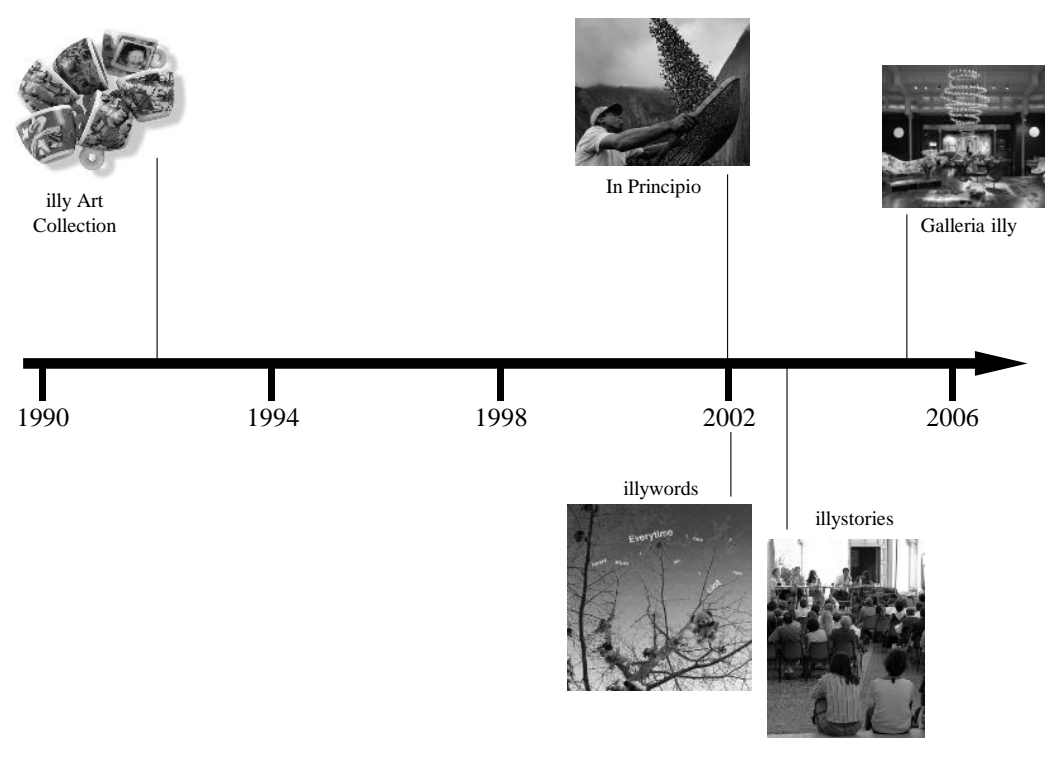

Figure 2: Timeline of cultural projects developed by illycaffè

\section{illy Art Collection (1992-) $)^{13}$}

As previously mentioned, the illy Art Collection is the name ${ }^{14}$ given to sets of truly special coffee cups designed by contemporary artists. Drinking coffee in a designer cup involves not only taste and smell but also touch and sight; furthermore, through sight, it involves the mind. With the illy Art Collection,

\footnotetext{
${ }^{12}$ In the article, we focus on cultural projects that have been developed by illycaffè for several years and are directly managed by the Italian company. For example, illy has participated in the Venice Biennial since 2003.

${ }_{13}^{13}$ www.illy.com/wps/wcm/connect/us/illy/art/illy-art-collection/

${ }^{14}$ Before 2006 the name was "illy Collection". The name "illy Art Collection" was introduced for the first time in 2006 with the Michael Lin series. These cups are always signed and numbered, and this inscription can be considered the natural evolution of the "illy Collection". "illy espresso" cups do not belong to the "illy Collection", lacking the signature, the number and the year inscription on the bottom. Some of the most important series or single limited edition cups of the collection were produced with the inside inscription "amici Collection".
} 
the company aims to involve its customers in an aesthetic and cultural experience. Art and creativity therefore become the languages used by illycaffè to express its values and philosophy. Francesco Illy is passionate about art. At the beginning of the '90s, he met the designer Matteo Thun; he commissioned the development of a new coffee cup able to involve all the five senses with a long and precise product brief. In 1992, Matteo Thun created this coffee cup (la tazzina di caffè, as he calls it), made exclusively of white china and soon to become the base of the next cups. The shape, as Thun said later, was all in that meticulous, scientific construction that left nothing to chance. It was almost inevitable then that it was not just an espresso cup that came into being, but rather the espresso cup, an archetype that, besides containing espresso, could also carry messages and narrate stories. During the years that followed, illycaffè collaborated with several contemporary artists; the collection is composed of cups of different shapes (coffee cup, cappuccino cup and mug), and each cup always has the artist's signature, the series number and the year of manufacture at the bottom.

"A good coffee is not enough: a banal cup makes banal also the moment to take an express coffee. Our challenge is to make a break for the express coffee a perfect aesthetical moment. This is our secret." 15

Carlo Bach, In-house Art Curator - illycaffè

\section{In Principio (2002-) ${ }^{16}$}

In Principio is a collaboration between the renowned humanitarian photojournalist Sebastião Salgado and illycaffè, based on their shared interest in improving the economic conditions of the men and women who grow coffee. This cultural project represents an opportunity for illycaffè to express one of its most important values: sustainable development. The project is described as a journey through the

\footnotetext{
${ }^{15}$ www.brandforum.it/sito/img_articoli/pdf/illy_intervista2.pdf

${ }^{16}$ www.illy.com/wps/wcm/connect/us/illy/art/sebastiao-salgado/
} 
origins of green coffee: Brazil, India, Ethiopia and Guatemala. It shows how men and women harvest, dry and select the coffee bean by bean. In Principio is thus a sort of tribute to the many people who work in the plantations, a trip to places where tradition and simplicity are special ingredients in producing one of the best mixtures in the world. The objective of this cultural project is to valorize the job of coffee cultivators, who are often reduced to poverty. Some of the photos developed by Sebastião Salgado were used also in the illy Art Collection (see Figure 3).

"My great hope is that my photos help to understand that behind the coffee that we drink there are men and women that cultivate it and pick up it, they are millions all over the world."

Sebastião Salgado, Photographer
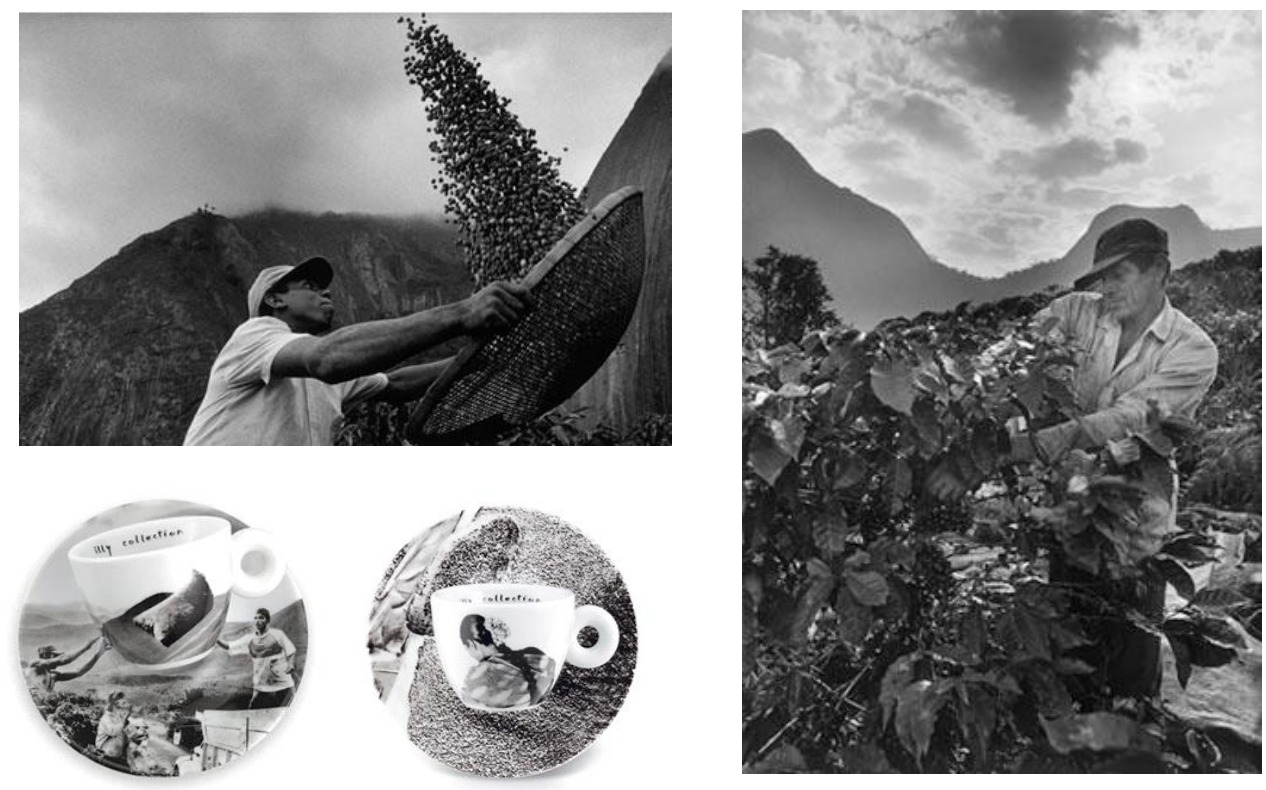

Figure 3: In Principio and illy Art Collection 


\section{illywords (2002-) $)^{17}$}

In 2002, illywords, which was initially conceived as a company magazine, became a public magazine distributed during the most important cultural events in the design and art worlds, in conjunction with participating bookshops and several major museums throughout the world. The aim of this cultural project is to connect the enormous network of relationships and contacts that illycaffè has created over decades, creating a continuous dialogue with these artistic and cultural spheres. The magazine allows one to reflect on the value of knowledge and different cultures; it engages several topics such as dreams, space, courage, awareness, chaos, etc. Journalists, writers, poets, chefs, designers, and others express their visions about emerging phenomena. illywords represents the opinions of people who belong to completely different countries, cultures and professions in order to underline the complexity and the variety of existing points of views. Each issue is illustrated with images by students from art and design schools throughout the world. Thanks to Illywords, the firm has established a very intimate relationship with people who love to read and reflect, who want to know about the art and cultural worlds.

\section{illystories (2003-) $)^{18}$}

illystories is a series of small books distributed free of charge in Italian coffee bars that serve illy, with stories short enough to finish in the time it takes to enjoy an espresso. The cultural project was conceived by illycaffè after a meeting with the organizers of "Scritture Giovani" (Young Writings) at the Festivaletteratura in Mantua in 2003; illycaffè decided to give young European writers the chance to express themselves through their short stories. Originally created to promote young European writers, illystories has also included stories developed by established authors since 2005 . The first edition, published in 2005, was dedicated to travel and featured the stories of four Italian writers and an

\footnotetext{
${ }^{17}$ www.illy.com/wps/wcm/connect/us/illy/art/illywords/

18 www.illy.com/wps/wcm/connect/us/illy/art/illystories/
} 
Irishman. In 2006 the cultural project explored the theme of the coffee house as a meeting place; finally, the third edition, published in 2007, focuses on expression as the result of a creative effort.

\section{Galleria illy (2005-) ${ }^{19}$}

Galleria illy is the last cultural project introduced by illycaffè; it is a an on-going timed event and aims to show a place where the products, expressions, passions and people of the illy world all come together, ready to be discovered. Galleria illy is a multifunctional space not only for consuming coffee but also for design shows, performances by young musicians, and appearances by famous chefs and writers. Galleria illy was initially established in New York in 2005 and then in Milan in 2006. In Italy the Galleria illy was presented in the showroom of Moroso, a leading Italian upholstery company. Galleria illy is the most fitting space in which to intensely live the illy experience: the coffee, accompanied by a sophisticated menu, the expressive images of the illy Art Collection, the art books, some previews about the reportages developed by Sebastião Salgado, etc.

\section{DISCUSSION}

The cultural projects developed by Diesel aim to enrich its brand with new meanings and values. As explained by Renzo Rosso, these projects, coherently proposed along with other communicative tools (website and advertising), contribute to represent Diesel as "a young brand, rather than a fashion brand".

"I would like that Diesel will be remembered as a brand that gives a chance to young people."

\footnotetext{
${ }^{19}$ www.illy.com/wps/wcm/connect/us/illy/art/project/galleria-illy/
} 


\section{Renzo Rosso, President - Diesel}

Basically, all cultural projects give young artists the opportunity to express themselves and to emerge; in this way, Diesel supports the activities of emergent artists. There are several reasons that have convinced Diesel to develop several cultural projects. The decision to activate cultural projects in specific "cultural territories" was undertaken in a rigorous and systematic way: in 2001, the company approached the music world with its first cultural project (Diesel-U-Music), then it connected its brand with other categories of art such as painting and photography (Diesel New Art in 2003), and finally it explored the world of installation art with Diesel Wall (2004). Diesel decided to enter into these cultural territories because it is particularly connected to young communities but, at the same time, it can make art approachable for young people, which is important because art is very often interpreted as a static and stuffy topic. These connections allow the company to intercept emergent cultural phenomena: through these cultural projects, Diesel can interpret even weak signals that have the potential to become the trends of the future. Diesel-U-Music, Diesel New Art and Diesel Wall can be interpreted as antennae that allow Diesel to listen to what is happening in the youthful quarters of society. As argued by Holt (2003), the most successful icons rely on intimate and credible relationships with a rebel world; cultural projects allow one to identify the appropriate direction of the rebellion because one can sense and anticipate what will happen in the future. Moreover, future scenarios described by the cultural projects are co-produced by Diesel, consumers, young talents and cultural experts. Members of the juries that select winning songs in Diesel-U-Music or the best installations in Diesel Wall represent some of the greatest experts in different categories of art, and again, through their decisions, they support Diesel in the interpretation of cultural phenomena. Diesel underlines the role of young talents/customers; in fact, Diesel-U-Music, Diesel New Art and Diesel Music are basically art competitions open to everybody. Diesel plays the role of cultural intermediary, taking care of the 
realization and distribution of cultural concepts. The co-production of cultural outputs (songs, paintings, installations, etc.) allows for a strong connection between the brand and consumer communities. They interpret Diesel as a representative brand, a company that provides them with the opportunity to give worldwide expression to values and ideas produced by its customers (see Table 1). Having reached a level of real excellence in the production process and in the quality of its blend, illy has spent the last decade focused on all aspects that surround the coffee world: with the illy Bar Concept $^{20}$ and Francis Francis espresso machines ${ }^{21}$, the company aims to enrich the coffee experience at home and away from home, while with the illy Art Collection, In Principio, illywords, illystories and Galleria illy, the company imbues its brand with innovative values and stories. As underlined by Ariella Risch ${ }^{22}$, this path from product excellence to the experience and then to the cultural value of coffee mainly derives from the ability of the Illy family to experiment and enter into the artistic and cultural worlds.

"Anyone seeking excellence in taste will not satisfy himself with a compromise: he wants a unique, complete experience that stimulates the senses and opens a world of emotions."23 Giacomo Biviano, General Director of EMEA markets - illycaffè

illycaffè has demonstrated through several cultural projects that it understands the increasing importance of the most immaterial components, those that are intangible and strongly connected with the affective dimension of the consumer. Pursuing this strategy, illycaffè has developed a brand identity

\footnotetext{
${ }^{20}$ illy Bar Concept (recently re-named Espressamente illy) is an architectural project developed in collaboration with Claudio Silvestrin and Luca Trazzi to furnish over 200 cafés in 32 countries on 5 continents. Each provides an authentic Italian coffee experience, starting with its design.

${ }^{21}$ Francis Francis espresso machines are a true marriage of striking Italian design and state-of-the-art technical innovation, crafted for the sole purpose of creating the perfect espresso experience in the home (www.illy.com).

${ }^{22}$ Ariella Risch is the Chief Manager for Editorial Projects and Sponsorships - illycaffè (interview developed by Claudio Dell'Era, February $\left.13^{\text {th }}, 2007\right)$.

${ }^{23}$ www.probrands.ro/index-en/illy-coffee/about-illy/illy-and-the-arts.html.
} 
that is particularly strong and distinctive, positively perceived by the market and appreciated by consumers. The cultural projects represent effective tools for both communicating the company identity and innovating on it. illycaffè's projects are different from Diesel's in that they focus strongly on collaboration with élite circles (Pisano and Verganti, 2008) rather than with consumers. In fact, with the exception of illystories, its cultural projects are developed in collaboration with selected artists, photographers, designers, etc. illy's strategy is less intensely oriented towards young talents/consumers. Consequently the co-production of future scenarios is probably less extensive (involving fewer people) but much more intensive (involving experienced artists); briefs proposed in cultural projects developed by illy are much more focalized in comparison with those produced by Diesel. This requires significant investments in the setting phase of the cultural projects as care is taken to identify the appropriate artist and develop the brief. In contrast, Diesel's cultural projects are characterized by significant investments in the analysis and evaluation of proposed concepts. Cultural projects developed by illycaffè aim to legitimize the presence of the company in the art and cultural world and to develop a strong art community, rather than a consumer community. The collaboration with famous artists allows illycaffè to be part of cultural circles and consequently to participate to the cultural production processes. If the cultural territories approached by some of Diesel's projects are particularly youthful (especially music), illywords and especially illystories approach a cultural territory such as literature, which is much more reflexive and introspective. Differently from Diesel, through its cultural projects, illycaffè can develop strong connections with different kinds of famous artists that share similar ideas and visions about the cultural values of the coffee (see Table 1). 


\begin{tabular}{|l|l|l|}
\hline & Diesel & illycaffè \\
\hline Objectives & - Interception of emergent & - Legitimization to be part of \\
& cultural phenomena & the art and cultural world \\
& - Co-production of future & - Co-production of future \\
& scenarios in collaboration & $\begin{array}{c}\text { scenarios in collaboration } \\
\text { with artists and cultural }\end{array}$ \\
& with consumers and young & experts \\
\hline Targeted community & talents & Artists / Cultural experts \\
\hline Collaboration with external actors & Open & Closed \\
\hline Path through cultural territories & Music $\rightarrow$ Visual art $\rightarrow$ & Visual art $\rightarrow$ Literature $\rightarrow$ \\
& Installation art & Installation art \\
\hline
\end{tabular}

Table 1: Principal characteristics of cultural projects developed by Diesel and illycaffè

The cultural projects developed by both companies allow to improve their forward looking capability; the distributed collaboration with several external actors increases the sensing capability of the companies towards weak signals that can determine future trends. If the insights coming from cultural projects developed in collaboration with consumer communities can be easily transferred in the core business (e.g. paintings coming from Diesel New Art can be evaluated to design new jeans) in order to generate competitive advantage, stimuli coming from cultural projects developed in collaboration with artists marginally impact the core business but generate intriguing opportunities for alternative business (e.g. the quotation of coffee cups developed through illy Art Collection goes from $50 €$ to 3.000€). As argued by Comunian (2008), the economical benefits generated by cultural projects are several; coherently with the results previously presented, she offers some examples of Italian companies (one of them is illycaffè) using their investments in arts and culture strategically to bolster their competitive position. More in detail she provides four different interpretations of the connections between art/culture and business:

- Cultural projects can represent Research and Development activities because they allow to intercept emerging cultural phenomena and consequently they are able to shape investments and strategies; 
- Cultural projects allow to communicate with audience sharing brand values and meanings, reinforcing consumer communities;

- Cultural projects can be interpreted as platforms facilitating the dialogue with different stakeholders such as consumers, suppliers, institutions, companies that operate in different industries;

- Cultural projects can improve the local context in physical and social terms; they can enrich not only the dialogue with consumers, but also with workers and local context developing a strong identity.

\section{CONCLUSIONS}

As previously mentioned, an increasing number of companies are trying to develop brands and products able to capture customers' attention by expressing emotions, messages, and values. Today, more than ever, products determine their own market presence through the meanings that they assume and the symbolic value that they exude. The cultural aspects of products and brands are so relevant that lately several companies have aimed to link arts and business to improve both society and corporate performance. If in the '90s keystone literature contributions from Pine and Gilmore (1999), Schmitt (1999c), and Schmitt and Simonson (1997) provided interesting and stimulating visions, recent phenomena seem to show the necessity of providing something more than an experience . Gilmore and Pine (2007) describe the concept of authenticity as the new business imperative; Holt (2004) demonstrates the success of some iconic brands with particular cultural connections. Focusing on two Italian companies (Diesel and illycaffè) that do not operate in the cultural industries but can be considered cultural producers, we analyzed several cultural projects, explaining their potential contribution to these companies' competitive advantage. The empirical study has shown several 
objectives that can reached through cultural projects. First of all, as underlined by Carlos Bach, collaboration with artists allows firms to intercept and to interpret emerging cultural phenomena and consequently to anticipate future trends. In this view, cultural projects act as antennas that pick up the signals being sent by contemporary society and thereby anticipate upcoming changes.

"From my point of view, the art and the art world represent the most sensitive part of the society in relation to the spirit of the time. For this reason the connection with the contemporary art allows illycaffè to exude a sense of being contemporary and to anticipate a vision of the society and the future markets. I would say that the contemporary art is as a map, an indication about the state of the things, of the spirit across time. This connection with the art can offer some very important indicators for companies. ${ }^{24}$

Carlo Bach, In-house Art Curator - illycaffè

The Romantic poet Percy Bysshe Shelley claimed that "Poets and philosophers [artists] are the unacknowledged legislators of the world." Moreover, collaboration with famous artists legitimizes companies as part of cultural production. As previously mentioned, Diesel plays the role of cultural intermediary by organizing several art competitions open to everybody and by facilitating the realization and distribution of cultural concepts, while illycaffè prefers to adopt a closed model where artists are identified and selected in the setting phase of cultural projects. In both cases, these cultural projects represent a sort of distributed research project that allows the co-production of future scenarios in collaboration with several categories of actors, such as famous artists, young talents, and consumers. Finally, the co-development of cultural projects with external actors allows firms to reinforce connections and build communities of people who share similar visions and values. Cultural projects

\footnotetext{
${ }^{24}$ http://www.brandforum.it/sito/img_articoli/pdf/illy_intervista2.pdf
} 
and consequently brands become containers of artistic and, in some cases, consumer expression. As argued by Holt (2004), consumers seek brands that allow them to develop and enrich their own identities, and cultural projects allow firms to match consumers' imaginations, to stimulate their cultural reflections, and to support the interpretation of the world that surrounds them. Even if both analyzed companies have paid significant attention towards art and culture since their establishment, the development of cultural projects is mainly concentrated in the mature phase: Diesel was established in 1978 and the first cultural project (Diesel-U-Music) was organized in 2001, illycaffè was founded in 1933 and the first cultural project (illy Art Collection) was developed in 1992. As previously mentioned, cultural projects legitimize companies to be part of the art world and enrich a cumulative asset represented by a network of relations with artists, cultural experts and young talents. At the same time, they can be developed after a series of small and more traditional investments in communication and public relations. In other words Diesel started to organized international competitions only when its brand and Renzo Rosso's fame were worldwide recognized; cultural projects can enrich the brand position and adjourn it considering the context evolution.

However, future studies will have to face some of this paper's limitations, such as the economic factors behind the development of cultural projects. The deep analysis of investments necessary to develop different kinds of cultural projects can provide additional information to managers who aim to enrich the cultural value of their brands and products. The study of the relationships between cultural projects and core business can provide further reflections; for example, insights and stimuli coming from Diesel New Art can be evaluated to design new jeans. Finally, the identification of other companies that develop cultural projects and operate in different industries can provide additional information and make research on this subject more robust. 


\section{ACKNOWLEDGMENTS}

The author would like to acknowledge Douglas Holt (Said Business School, University of Oxford) and especially Roberto Verganti for their insightful inspirations, Alessio Marchesi and Stefano Reghellin (Politecnico di Milano), whose contribution was tireless and invaluable during the entire research process. Naturally, any mistakes or omissions are the sole responsibility of the author. Financial support from the FIRB fund "ART DECO - Adaptive InfRasTructures for DECentralized Organizations" is also gratefully acknowledged.

\section{REFERENCES}

1. Aage $\mathrm{T}$ and Belussi F (2008). From Fashion to Design: Creative Networks in Industrial Districts. Industry and Innovation, Vol. 15, No. 5, Pp. 475-491.

2. Addis M and Holbrook MB (2001). On the Conceptual Link Between Mass Customization and Experiential Consumption: An Explosion of Subjectivity. Journal of Consumer Behaviour, Vol. 1, No. 1, pp. 50-66.

3. Arvidsson A (2005). Brands: A critical perspective. Journal of Consumer Culture, Vol. 5, No. 2, Pp. 235-258.

4. Batra R and Ray ML (1986). Affective Responses Mediating Acceptance of Advertising. Journal of Consumer Research, Vol. 13, Pp. 234-249.

5. Becker HS (1974). Art as Collective Action. American Sociological Review, Vol. 39 (December).

6. Becker HS (1982). Art Worlds. Berkeley, CA, University of California Press.

7. Benetton Group S.P.A. (1992). United Colors: A brief history. [Brochure]. New York.

8. Berthon P, Holbrook MB and Hulbert JM (2003). Understanding and Managing the Brand Space. Sloan Management Review. 
9. Bloch PH, Brunel F and Arnold TJ (2003). Individual differences in the centrality of visual product aesthetics: concept and measurement. Journal of Consumer Research 29, 551-565.

10. Comunian R (2005). Culture Italian style: business and the arts. Journal of Business Strategy, Vol. 29, No. 3, Pp. 37-44.

11. Dars $\varnothing$ (2005). International opportunities for artful learning. Journal of Business Strategy, Vol. 26, No. 5, Pp. 58-61.

12. Dumaine B. (1991). Design that sells and sells and ... After years of ferocious competition on price and quality, many companies believe superior design will be the key to winning customers in the Nineties.

http://money.cnn.com/magazines/fortune/fortune_archive/1991/03/11/74762/index.htm

13. Du Gay P (Ed.) (1997). Production of Culture: Cultures of Production. London: Sage.

14. Fulberg P (2003). Using sonic branding in the retail environment - An easy and effective way to create consumer brand loyalty while enhancing the in-store experience. Journal of Consumer Behaviour, Vol. 3, No. 2, Pp. 193-198.

15. Gardner MP (1985). Does Attitude Toward the Ad Affect Brand Attitude Under a Brand Evaluation Set?. Journal of Marketing Research, Vol. 22, Pp. 192-198.

16. Gardner BB and Levy SJ (1955). The Product and the Brand. Harvard Business Review, MarchApril, Pp. 33-39.

17. Gilmore JH and Pine BJ (2007). Authenticity - What consumers really want. Harvard Business School Press.

18. Grubb EL and Grathwohl HL (1967). Consumer Self-Concept, Symbolism and Market Behavior: A Theoretical Approach. Journal of Marketing, Vol. 31, Pp. 22-27.

19. Havlena WJ and Holbrook MB (1986). The Varieties of Consumption Experience Comparing Two Typologies of Emotion in Consumer Behavior. Journal of Consumer Research, Vol. 13. 
20. Hawes DK (1978). Satisfactions Derived From Leisure-time Pursuits: An Exploratory Nationwide Survey. Journal of Leisure Research, Vol. 10, No. 4, Pp. 247-264.

21. Hesmondhalgh D (2002). The Cultural Industries. London: Sage.

22. Hirsch P (1972). Processing fads and fashions: an organization-set analysis of cultural industry systems. American Journal of Sociology, Vol. 77, Pp. 639-659.

23. Hirschman EC (1980). Attributes of Attributes and Layers of Meaning. In Advances in Consumer Research. Vol. 7, Pp. 7-12, Association for Consumer Research, Ann Arbor, MI.

24. Hirschman EC (1982). Symbolism and Technology as Sources for the Generation of Innovations. Advances in Consumer Research, Vol. 9 (Ann Arbor, MI: Association for Consumer Research), Pp. 537-541.

25. Holbrook MB and Hirschman EC (1982). The Experiential Aspects of Consumption: Consumer Fantasies, Feelings, and Fun. Journal of Consumer Research, Vol. 9, pp. 132-140.

26. Holbrook MB and O’Shaughnessy J (1984). The Role of Emotions in Advertising. Psychology and Marketing, Pp. 45-64.

27. Holbrook MB, Chestnut RW, Oliva TA and Greenleaf EA (1984). Play as a Consumption Experience: The Roles of Emotions, Performance, and Personality in the Enjoyment of Games. Journal of Consumer Research, Vol. 11, Pp. 728-739.

28. Holbrook MB, Lehmann DR and O'Shaughnessy J (1986). Using Versus Choosing: The Relationship of the Consumption Experience to Reasons for Purchaising. European Journal of Marketing, Vol. 20, No. 8.

29. Holt DB (2002).Why Do Brands Cause Trouble? A Dialectical Theory of Consumer Culture and Branding. Journal of Consumer Research, Vol. 29, Pp. 70-90.

30. Holt DB (2003). What becomes an icon most? Harvard Business Review.

31. Holt DB (2004). How brands becomes icons. Harvard Business School Press. 
32. Joy A and Sherry JF (2003). Speaking of Art as Embodied Imagination: A Multisensory Approach to Understanding Aesthetic Experience. Journal of Consumer Research, Vol. 30.

33. Kozinets RV (2001). Utopian experience: Articulating the Meanings of Star Trek's Culture of Consumption. Journal of Consumer Research, Vol. 28 (June), Pp. 67-88.

34. Kozinets RV (2002). Can Consumers Escape the Market? Emancipatory Illuminations from Burning Man. Journal of Consumer Research, Vol. 29 (June): Pp. 20-38.

35. Lash S and Urry J (1994). Economies of Sign and Space. London: Sage.

36. Levy SJ (1959). Symbols for Sale. Harvard Business Review, Vol. 37 (July-August), Pp. 117124.

37. McCracken G (1988). Culture and Consumption. Bloomington: Indiana University Press.

38. Mizerski RW and White JD (1986). Understanding and Using Emotions in Advertising. The Journal of Consumer Marketing, Vol. 3, No. 4.

39. Peterson RA and Anand N (2004). The production of culture perspective. Annual Review of Sociology, Vol. 30, Pp. 311-334.

40. Peterson RA, Wayne DH and Wilson WR (1986). The Role of Affect in Consumer Behaviour: Emerging theories and Applications, Lexigton, MA: D.C. Heath.

41. Pine BJ and Gilmore JH (1998). Welcome to the Experience Economy. Harvard Business Review, July-August 1998.

42. Pine BJ and Gilmore JH (1999). The Experience Economy - Work is Theatre \& Every Business a Stage. Harvard Business School Press.

43. Pisano GP and Verganti R (2008). Which kind of collaboration is right for you? Harvard Business Review, December.

44. Postrel V (2001). Aesthetics and instrumentality: can good looks guarantee a product's success? Available at http://www.nytimes.com/2001/07/12. 
45. Postrel V (2003). The Substance of Style. Harper Collins Publishers, New York.

46. Schmitt B (1999a). Experiential Marketing. Journal of Marketing Management, Vol. 15, pp. 5367.

47. Schmitt B (1999b). Experiential Marketing: A New Framework for Design and Communications. Design Management Journal, Vol. 10, No. 2, Pp. 10-16.

48. Schmitt B (1999c). Experiential Marketing - How to Get Customers to Sense, Feel, Think, Act and Relate. The Free Press.

49. Schmitt B and Simonson A (1997). Marketing Aesthetics - The Strategic Management of Brands, Identity, and Image. The Free Press.

50. Smelser NJ (1973). Sociology Second Edition. New York, John Wiley \& Sons.

51. Solomon MR (2003). Consumer Behavior: Buying, Having and Being. Saddleback, NJ: Prentice Hall.

52. Staber U (2008). Network Evolution in Cultural Industries. Industry and Innovation, Vol. 15, No. 5, Pp. 569-578.

53. Tinic SA (1997). United Colors and United Meanings: Benetton and the Commodification of Social Issues. Journal of Communication.

54. Tinsley HEA and Kass RA (1978). Leisure Activities and Need Satisfaction: Replication and Extension. Journal of Leisure Research, Vol. 9, Pp. 381-392.

55. Unger LS and Kernan JB (1983). On the Meaning of Leisure: An investigation of Some Determinants of the Subjective Experience. Journal of Consumer Research, Vol. 9, Pp. 381392. 